\title{
Behavioural evolution of consumers of banking services in the COVID-19 pandemic situation
}

\author{
Larisa MISTREAN ${ }^{\mathrm{a}}$ \\ a Associate Prof. Dr. Academy of Economic Studies of Moldova, Department of Investments and Banking Activity, Republic \\ of Moldova
}

\section{A B S T R A C T}

Managing customer relations is one of the main contemporary challenges facing banks, especially in terms of new social changes and major changes in human behaviour, generated by the COVID-19 crisis. The currently drifting economic climate affects all of the existing and potential customers and consumer behaviour, being much more demanding on the products and services purchased, their particularities, the conditions proposed by banks, prices and the bankcustomer relationship.

The new segmentation generated by the pandemic puts additional pressure on banks, which have a difficult task: to better understand these new behaviours and to meet consumer requirements with relevant products and convenient services. Whatever the options, banks must be receptive to the current needs of consumers of financial products and services and to the behaviour they must adopt in order to remain relevant on the market.

The general objective of this study is to provide a practical perspective on the impact of the pandemic crisis on consumer behaviour of banking products and services.

\author{
A R T I C L E I N F O \\ Keywords: \\ Consumer Behaviour, The COVID- \\ 19 Pandemic, Internet and Mobile \\ Banking, Banking services, Remote \\ Banking Systems
}

*Corresponding author:

mistrean_larisa@yahoo.com

\section{Article history:}

Received 08.01.2021

Revised 21.02.2021

Accepted 27.04.2021

DOI:https://doi.org/10.51410/jcgirm.8.1.6

\section{INTRODUCTION}

The COVID-19 crisis has generated, in a very short time, a transformation in the way people buy and consume. Coronavirus concerns cause customers to deeply adjust their behaviour in the buying process. The severe economic shock caused by the COVID-19 pandemic and the exceptional measures to limit its spread have a profound negative impact on banking consumers. Businesses are facing supply chain disruptions, temporary closures and reduced demand, and individuals are facing unemployment and declining incomes. In the case of the Republic of Moldova, all these negative effects that influence the behaviour of consumers of banking products and services are amplified by the political crisis that persists. Even under these conditions, banks are responsible for maintaining liquidity flows and should continue to assume their duty to finance the economy, to continue to lend to individuals and businesses, within the limits of prudent behaviour. 
However, the current crisis is at the same time an opportunity to change the banking business, which requires additional efforts, collaboration, customer involvement, as well as a rethinking of the development model and exploring new opportunities of the bank-customer relationship. These involve not only the digitalisation and modernization of financial services and the activity of banks, but also the development of skills and a modern education system for the consumer of banking services and the promotion of a sustainable bank-customer relationship.

\section{LITERATURE REVIEW}

Ensuring compliance in consumer protection will have an increasing impact on the banking sector. The impact of COVID-19 on consumer behaviour of banking products and services has been reflected in several researches and market studies.

The effect of the COVID-19 crisis was felt in the public and private sectors, and at the social level, changing consumer preferences, but also the way it relates to current and future activities. Researchers (Cârstoiu, 2020) observed similar patterns of the Romanian consumer with the consumers from other countries such as the USA, the United Kingdom, France or Germany. These changes are expected to be long-lasting, depending on the constraints and evolution of COVID-19 (and its economic impact). Therefore, banks will have a difficult task: to better understand these new behaviours and to meet the requirements of consumers with relevant products and convenient services, respectively, to adapt their business models to social changes related to the COVID-19 crisis.

The measures imposed by the authorities on lockdown and social distancing to reduce the spread of the virus have led to a considerable increase in the number and value of online transactions. Craven (2020) considers that “Customers' changing preferences are not likely to go back to preoutbreak norms". Changing the consumer behaviour of customers will lead to a transformation of the business model of banks, especially the modernization of distribution channels as the most affected banking dimension (Pop, 2020).

Baicu (2020) states that retail consumers have been forced to use predominantly cashless payments at the expense of cash and digital channels rather than traditional channels, striving to adapt and fully accept new channels and technologies.

Certain trends in consumer behaviour have been identified, driven by measures to limit physical contact and cash use during the pandemic: the value of account balances with digital banks in Southeast Asia has increased; the process of opening online bank accounts by small and medium-sized enterprises in Malaysia has intensified; the limit for contactless payment in the UK has been increased (Hoe, 2020).

Current developments bring digital payments to the fore (Auer, 2020). At the moment not all digital payments are immune. For instance, debit and credit card transactions generally require a signature or a PIN entry at a merchant owned device for larger transactions. Contactless card payments, which are 
popular in several countries, do not require a PIN for small transactions. Recently, authorities, banks and card networks in Austria, Germany, Hungary, Ireland, the Netherlands, the United Kingdom and elsewhere have set higher transaction limits for contactless payments. Digital wallets or other smartphone-based payment interfaces (e.g. stored card details or QR codes) where no physical contact of the same object by multiple persons takes place are further potential solutions.

The Monetary Authority of Singapore (Coelho, 2020) has requested financial institutions to implement safe distancing measures in all aspects of their business operations, especially customer touch points. The Federal Financial Institutions Examination Council recommends that banks consider providing employees with appropriate hygiene training and tools and implementing social distancing techniques to reduce face-to-face contact by using, for example, teleconference calls, flexible work hours and telecommuting. The European Central Bank calls for banks to establish adequate measures of infection control in the workplace and highlights the importance of worker education. With the same objective, the Central Bank of the United Arab Emirates directs banks to replenish automated teller machines (ATMs) with unused banknotes.

In order to reduce consumer dependence on territorial subdivisions, banks should encourage the use of remote services by launching "positive and safety-oriented messaging” (Buehler, 2020). From this perspective, banks need to take into account the degree of access to products and services of all consumer segments, especially for older people, who are more reluctant to use digital services. In this context, banks should simplify their online interfaces and provide support to customers, including educational materials on how to use online channels (eMarketer, 2020). For example, Singapore's DBS bank has organized webinars and personalized courses to train its customers and facilitate their use of digital channels (Finextra, 2020).

Under current conditions, banks should develop digital capabilities that ensure a "human touch", allowing them to better interact with customers and really support them in the buying process (for example, live chat or video calls) (Vessey, 2020). McCarty (2020) also emphasizes the importance of chat for consumers of banking products and services during the social distancing imposed by Covid19.

The transition to digital payments could have a negative impact on older and non-bank consumers, which necessitates the maintenance and use of cash in circulation (Auer, 2020).

To bolster trust in cash and guarantee universal acceptance, several central banks have actively communicated that risks are low and taken further actions. The Bank of England (2020) has noted that "the risk posed by handling a polymer note is no greater than touching any other common surfaces such as handrails, doorknobs or credit cards". The Bundesbank has advised the public that the risks of transmission through banknotes are minimal and that a sufficient supply of banknotes is guaranteed. The Bank of Canada has asked retailers to stop refusing cash payments. The South African Reserve Bank has counteracted scams by clarifying that there is no evidence of transmission by cash and it is not withdrawing cash from circulation. The People’s Bank of China began in February to sterilise 
banknotes in regions affected by the virus. The Fed confirmed that it was quarantining bills arriving from Asia prior to recirculation. Central banks in South Korea, Hungary, Kuwait and other countries have also moved to sterilise or quarantine banknotes, and thus ensuring that cash leaving central bank currency centres does not carry pathogens. Central banks or governments in India, Indonesia, Georgia and several other countries have encouraged cashless payments (Auer, 2020).

The Deloitte Global Marketing Trends 2021 study (Deloitte, 2021) points out that the current context is rapidly changing the behaviour of consumers, who seem to prefer digital channels, $66 \%$ saying that the pandemic has made them appreciate quality technology solutions more. The health crisis has contributed not only to the transition to digital technologies, but also to the creation of a model for the coming years. According to the results of the study, $63 \%$ of respondents say they will continue to use digital technologies more often even after the pandemic ends.

The migration to digital channels has proved imperative for the banking sector; the next step is their development for the post-COVID-19 reality, which will increasingly focus on online and business adaptability.

Globally, there is a new consumer, who is financially constrained, who is much more advanced in the use of digital technologies and is more careful and selective in making purchasing decisions.

The KPMG (2020) study "Adapting to the evolution of consumers in the new reality" shows that COVID-19 has a global and lasting impact on consumer needs, preferences and behaviours, which determines the need for companies to change their thinking and way of operating in accordance with these changes.

The results of this survey showed that the top priorities for consumers of the banking products and services are value for money and personal security, as well as ease of access (including better functionality of the bank's website and remote service applications). Research shows that trust is a key attribute for banking (45\%), with research showing a clear improvement of trust in the bank (+ 15\%), almost all consumers are saying that trust in their bank is at least as much as before COVID-19 (96\%) (KPMG, 2020).

Understanding how consumers act can help shape the future product and meet distribution preferences in a post-COVID-19 era (PwC, 2020). Banks will need to respond to lasting social change, including how consumers select products and distribution channels, to meet individuals' financial needs. Behavioural changes may accelerate the shift of the branch concept away from transactions toward a more complex, high-value operation. Decisions on how to distribute and the relevance of the product will be the key to successful banking. Customers are increasingly expecting individualized offers, and banks will need to use their databases to manage their customers, products, and pricing strategy to fully meet their expectations.

It is obvious that new - digital banks need to work harder to increase the level of consumer confidence, they need to promote the key factors that best suit their offer (digital security, ease of use, and value for money).

PAGE 87| Journal of Corporate Governance, Insurance, and Risk Management | 2021, VOL. 8, Series. 1 
In order to provide individuals and businesses with the benefits of digital financial services, to facilitate the interoperable use of digital identities across the EU and to eliminate fragmentation of the EU digital market, the Digital Finance Strategy has been developed. A functioning single market for digital financial services will help improve access to financial services for consumers and retail investors in the EU through more innovative, diversified and inclusive banking, investment and insurance services (CE, 2020). By 2024, the EU should implement a sound legal framework that allows for the use of interoperable digital identity solutions, allowing new customers quick and easy access to financial services ("on-boarding").

The transfer of business activity in the online environment was the rapid measure adopted by Moldovan banks, because the use of digital tools allows for the increase of resource efficiency, productivity, but also competitive power. (Economic, 2020)

Melamedov (2020) underlines that adoption of digital solutions will have an impact on the long term, even after the coronavirus pandemic and the traditional banks have to learn from the experience of digital financial institutions "neobanks" and fintechs, and partnerships with fintechs could be a way for banks to introduce new products and services (World Economic Forum, 2020).

\section{DATA AND METHOD}

Our research aims to produce generalizable knowledge about the impact of the COVID-19 on the behaviour of the consumers of banking services. The researchers begin with specific observation, which are used to produce conclusions drawn from the research papers, Bank for International Settlements and others central banks publications and the National Bank of Moldova database, National Bureau of Statistics of the Republic of Moldova database. The content analysis was done in order to analyse the data, which was gathered from the statistics website and reports.

The research methods used include: analysis of statistical data, comparison, chain indices, and graphs. The obtained results showed that COVID-19 has led banks to react promptly to changes of consumer consumption behaviour. Among the methods of socio-human sciences, those that become complementary in this research are mainly: the analysis of the financial situation of consumers of banking services, analysis of the behavioural evolutions of the banking clients in the Republic of Moldova during COVID-19 crises; comparative method; observation. Next, the method of examination shows the evolution of the behaviour of the consumers of banking services in the Republic of Moldova and how banks can strategically respond to COVID-19 challenges.

\section{THE IMPACT OF THE COVID-19 ON CONSUMER FINANCE}

The slowdown in economic activity as a result of measures to prevent the transmission of the new coronavirus, such as reduced mobility, has had significant repercussions on the population's income. 
To better understand the impact that the coronavirus pandemic has on consumers of the banking products and services, we will analyse how the virus has affected their financial situation.

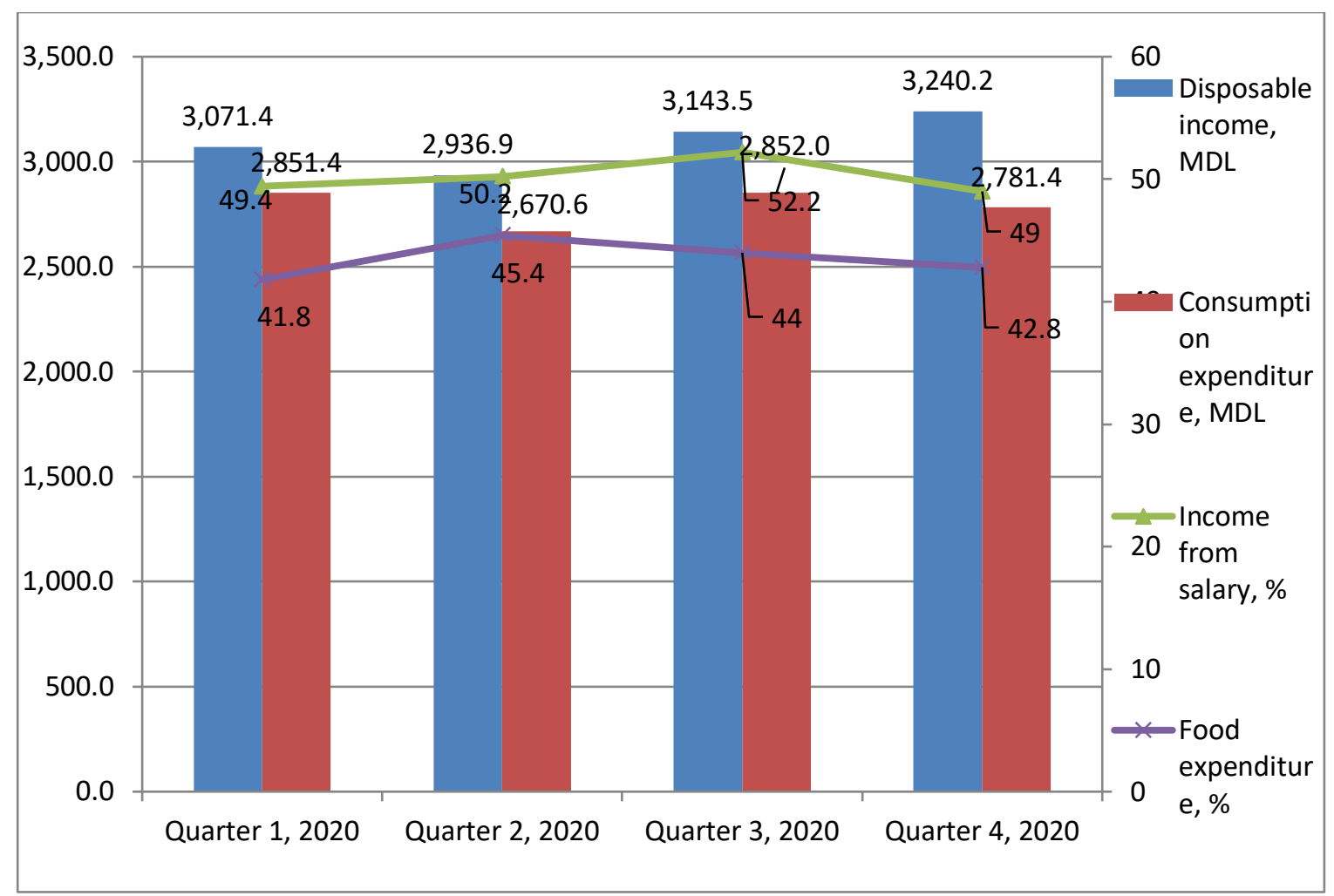

Figure 1: Evolution of the monthly value of personal income and expenses, MDL

According to the data of the National Bureau of Statistics in 2020, the disposable income of the population amounted to an average of 3096.6 MDL per person per month, increasing by $7.5 \%$ compared to the previous year. In real terms (with the adjustment to the consumer price index) the incomes of the population registered an increase of 3.6\%.

Earnings are the most important source of income of the population, with a share of $50.2 \%$ in total income, which remained at the level of the previous year. The available income of the population is divided in two: $92.8 \%$ comes from money sources, and the other $7.2 \%$ represent income in kind. In absolute values, the value of money income amounted to 2875.1 MDL per month on average per person, and those in kind - 221.5 MDL. Money revenues are more significant for the urban environment (96.8\%), and in the case of the rural population their contribution is $89.3 \%$.

The average monthly consumption expenditures of the population, in 2020, amounted to an average of 2791.2 MDL per person and remained practically at the same level of the previous year. In real terms (with the adjustment to the consumer price index) the population spent on average 3.5\% less compared to 2019. Most of the expenditure is for food consumption - 43.5\%. For housing and communal services, an average person allocated $16.1 \%$ of total consumption expenditures, and for clothing and footwear - 8.8\%. The other expenses were directed for housing (5.6\%), transport services (5.5\%), health (4.7\%), telecommunications (4.7\%), etc. 
However, many consumers have seen their personal finances negatively affected since the crisis hit. While lower disposable income and general economic uncertainty have led to reduced spending on clothing, services, gadgets and restaurants, spending on food has risen as consumers have stockpiled products.

Money transfers from abroad remain a significant source for individuals' budgets. On average, they represent $12.9 \%$ of total revenues or 0.5 percentage points more compared to 2019. The data presented in the Table 1 show that the value of transfers from abroad has increased considerably during the pandemic period, representing an important source of financing the need for financial resources of the population. It is obvious that about $65 \%$ of the value of transfers were made in euros and about a third in USD.

Table 1: Money Transfers from Abroad in Favor of Individuals, mil USD

\begin{tabular}{|c|c|c|c|c|c|}
\hline & \multicolumn{2}{|c|}{ Total inflows } & \multicolumn{3}{|c|}{ of which (share \%): } \\
\hline & Total & Including via banks & USD & EUR & RUB \\
\hline Jan 2020 & 86,65 & 71,31 & 37,9 & 59,1 & 3,0 \\
\hline Feb.. 2020 & 94,68 & 79,55 & 36,0 & 60,2 & 3,8 \\
\hline Mar.. 2020 & 95,13 & 76,44 & 38,1 & 57,4 & 4,5 \\
\hline Apr.. 2020 & 92,14 & 74,85 & 40,0 & 58,1 & 1,9 \\
\hline May 2020 & 134,54 & 115,34 & 36,8 & 61,6 & 1,6 \\
\hline June 2020 & 143,24 & 121,48 & 36,7 & 62,0 & 1,3 \\
\hline July 2020 & 148,82 & 124,92 & 36,2 & 62,4 & 1,4 \\
\hline Aug.. 2020 & 126,44 & 107,33 & 35,4 & 62,9 & 1,7 \\
\hline Sept.. 2020 & 148,87 & 124,95 & 35,0 & 63,0 & 2,0 \\
\hline Oct.. 2020 & 136,52 & 113,78 & 33,7 & 64,3 & 2,0 \\
\hline Nov.. 2020 & 131,87 & 108,75 & 32,8 & 65,3 & 1,9 \\
\hline Dec.. 2020 & 147,84 & 118,95 & 33,2 & 64,5 & 2,3 \\
\hline Jan 2021 & 105,82 & 85,56 & 32,9 & 64,9 & 2,2 \\
\hline Feb.. 2021 & 113,53 & 92,43 & 31,2 & 66,5 & 2,3 \\
\hline
\end{tabular}

The results of the research "Influence of the COVID-19 pandemic on the individuals" in the second quarter of 2020 accomplished by the National Bureau of Statistics of the Republic of Moldova showed that the COVID-19 pandemic created a number of impediments to the daily activities of individuals and significantly influenced their plans and intentions. At the same time, the pandemic, due to its magnitude, in addition to the socio-economic impact, has a considerable impact on the mood of the population.

The research data shows that the value of income and the structure of expenditure have undergone significant changes. Thus, the size of disposable income per person differs by groups of individuals depending on whether they experienced difficulties during the pandemic. Respondents who lost their jobs in the country have $37.4 \%$ lower incomes compared to individuals who continue to work.

At the same time, there are some differences between the consumption expenditures of individuals who faced difficulties during the pandemic. Food expenditure decreased by $15.8 \%$ and the value of savings used to cover daily expenses increased by $9.6 \%$. Individuals who lost their jobs spent about $17.5 \%$ less on themselves compared to those who continue to work. 


\section{TRENDS IN CONSUMER BEHAVIOUR AND ITS IMPACT ON BANKS ACTIVITY}

The pandemic imposed a different approach to the bank's activity in order to facilitate consumers' access to the necessary products. Banks from the Republic of Moldova have provided customers with online banking tools so that they can perform simple, convenient operations, anytime and anywhere, have automatically extended the validity of cards, implemented foreign exchange at ATMs, provided access to online sales tools, and announced measures to defer payments on loans to individuals and legal entities. Today, in addition to paying bills, credit instalments, and making online transfers, bank customers can open a deposit account through the web application, apply for loans online, exchange currency at ATMs and so on.

Despite the fact that the COVID-19 pandemic affected the financial situation of consumers of banking products, banks registered a positive evolution of the value of the main products, with few exceptions at the beginning of the period. Thus, in February 2021, the new deposits attracted on time amounted to 2234.5 million MDL, increasing by $17.4 \%$ compared to February 2020. The volume of attracted deposits constituted:

- $\quad$ in the national currency - 1462.0 million MDL (-2.6\% compared to the previous month and + 25.7\% compared to February 2020);

- in foreign currency recalculated in MDL - 772.5 million MDL (-3.1\% compared to the previous month and $+4.4 \%$ compared to February 2020).

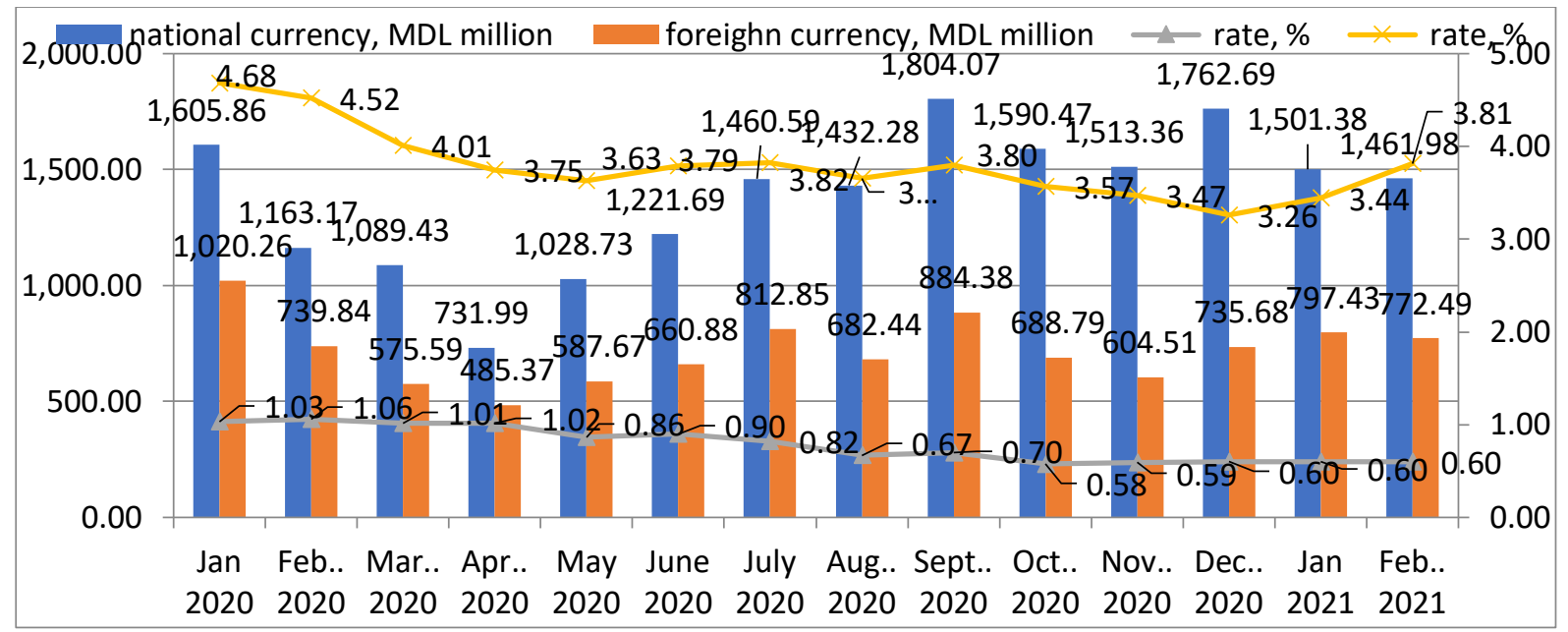

Figure 2: The weighted average interest rates and volumes on new attracted deposits

The share of deposits attracted in the national currency amounted to $65.4 \%$ while that in foreign currency amounted to 34.6\%. In April 2020, the new deposits in MDL the banks managed to attract decreased by 32.8\% when compared to March 2020 and by almost 55\% when compared to January 2020. According to the National Bank, in April the volume of new deposits in MDL was approximately 732 million MDL. In May, this amount was 1.03 billion MDL, and in February 2021 1.46 billion MDL, given that the interest rate is continuously decreasing, except for February. The 
value of new deposits in foreign currency had approximately the same evolution, only with much more modest amplitudes.

The new deposits were mainly represented by individual deposits amounting to 79.4\% (50.8\% being the deposits attracted in the national currency and $28.6 \%$ those in foreign currency). From the perspective of placement terms, the most attractive were deposits with terms from 6 to 12 months with a share of $29.0 \%$ of total deposits attracted on time (deposits of individuals accounted for $25.9 \%$ of total deposits).

The average rate for new deposits attracted in time in the national currency was 3.81\%, and for those in foreign currency - $0.60 \%$. Compared to the previous month, the average rate has evolved:

- $\quad$ the new deposits attracted on time in the national currency increased by $0.37 \mathrm{pp}$. Legal entities placed deposits with an average rate of $2.92 \%$, individuals who practice an activity with an average rate of $2.94 \%$, and other individuals with an average rate of $4.08 \%$;

- the new term deposits in foreign currency have not changed. Legal entities placed deposits with an average rate of $0.85 \%$, individuals who practice an activity with a rate of $0.50 \%$, and other individuals with an average rate of $0.55 \%$.

Compared to February 2020, the average rate on deposits in the national currency has decreased as did that of the foreign currency deposits. The new deposits from individuals decreased the most, both in MDL and in foreign currency. For example, for a year, the volume of new deposits in foreign currency decreased almost by half - from 867 million MDL to 448 million MDL.

Companies, on the contrary, have increased their placement of new deposits, especially in foreign currency. Compared to February 2020, their volume increased 2.5 times in March - from 57.5 million MDL to 127.6 million MDL. The same thing happened in the case of deposits in MDL of legal entities. These increased from 267 million MDL to 380 million MDL. However, if we compare the attraction of new deposits from legal entities in January and March, the volume of new deposits decreased by 15\% compared to January. Compared to March 2019, the total volume of legal entities' deposits increased by over 50\% - from 324.5 million MDL to 507.6 million MDL. Such differences in the volumes of deposits of legal entities attracted are caused by the fact that most often, they place short-term deposits for 1 month.

It should be mentioned that the total volume of all bank deposits in both MDL and foreign currency increased, from February to March 2020, by half a billion MDL, or by $0.3 \%$, to 70 billion MDL. However, this increase is mainly due to the devaluation by $0.5 \%$ of the Romanian leu in that period, as the volume of deposits of citizens and businesses in foreign currency increased, but decreased in MDL.

In February 2021, the new loans granted amounted to 2673.2 million MDL, increasing by $12.5 \%$ compared to February 2020. The structure of loans granted in the reporting month evolved as follows:

- $\quad 74.1 \%$ represent loans in national currency, which amounted to 1981.1 million MDL (+ 42.2\% compared to the previous month and $+21.7 \%$ compared to February 2020 );

PAGE 92| Journal of Corporate Governance, Insurance, and Risk Management | 2021, VOL. 8, Series. 1 
- $24.4 \%$ represent loans in foreign currency, whose volume recalculated in MDL amounted to 652.8 million MDL ( $+0.4 \%$ compared to the previous month and $-6.4 \%$ compared to February 2020);

- $\quad 1.5 \%$ belong to loans attached to the exchange rate, which amounted to 39.3 million MDL (44.3\% compared to the previous month and $-21.7 \%$ compared to February 2020).

Table 2: Average interest rate on interest bearing demand deposits in national currency

\begin{tabular}{|l|c|c|c|c|c|c|}
\hline & \multicolumn{2}{|c|}{ Business } & \multicolumn{2}{c|}{ Individuals performing an activity } & \multicolumn{2}{c|}{ Individuals } \\
\hline & amount, mil & rate, \% & amount, mil & rate, \% & amount, mil & rate, \% \\
\hline January 2020 & $9.006,15$ & 1,66 & 31,81 & 0,22 & $2.572,85$ & 0,92 \\
\hline February 2020 & $9.135,94$ & 1,68 & 22,66 & 0,22 & $2.805,70$ & 0,90 \\
\hline March 2020 & $8.487,63$ & 1,59 & 23,69 & 0,20 & $2.982,83$ & 1,04 \\
\hline April 2020. & $7.039,38$ & 1,37 & 18,56 & 0,21 & $2.530,58$ & 0,83 \\
\hline May 2020 & $6.931,48$ & 1,30 & 11,26 & 0,20 & $2.498,11$ & 0,82 \\
\hline June 2020 & $7.502,55$ & 1,21 & 13,39 & 0,21 & $2.459,74$ & 0,97 \\
\hline July 2020 & $8.145,41$ & 1,20 & 25,95 & 0,21 & $1.547,00$ & 1,23 \\
\hline August 2020. & $6.667,32$ & 1,14 & 20,89 & 0,21 & $1.386,94$ & 1,21 \\
\hline September 2020 & $8.394,61$ & 1,13 & 40,45 & 0,22 & $1.431,79$ & 1,23 \\
\hline October 2020 & $8.163,79$ & 1,16 & 39,26 & 0,22 & $1.486,88$ & 1,21 \\
\hline November 2020 & $8.488,51$ & 1,17 & 38,95 & 0,22 & $1.459,40$ & 1,16 \\
\hline December 2020 & $9.600,64$ & 1,33 & 60,48 & 0,20 & $1.810,58$ & 1,15 \\
\hline January 2021 & $8.427,07$ & 1,40 & 45,72 & 0,23 & $1.120,58$ & 1,18 \\
\hline February 2021 & $8.726,59$ & 1,40 & 28,85 & 0,31 & $1.289,76$ & 1,18 \\
\hline March 2021 & $9.987,06$ & 1,41 & 21,94 & 0,26 & $1.316,11$ & 1,18 \\
\hline
\end{tabular}

Table 3: Average interest rate on interest bearing demand deposits in foreign currency

\begin{tabular}{|l|c|c|c|c|c|c|}
\hline & \multicolumn{2}{|c|}{ Business } & \multicolumn{2}{c|}{ Individuals performing an activity } & \multicolumn{3}{c|}{ Individuals } \\
\hline & amount, mil & rate, \% & amount, mil & rate, \% & amount, mil & rate, \% \\
\hline January 2020 & 837,91 & 0,22 & 0,04 & 0,25 & 93,54 & 0,33 \\
\hline February 2020 & 591,05 & 0,23 & 0,08 & 0,25 & 101,82 & 0,31 \\
\hline March 2020 & $1.006,40$ & 0,24 & 0,00 & 0,25 & 85,78 & 0,32 \\
\hline April 2020. & 897,25 & 0,23 & 0,00 & 0,00 & 55,32 & 0,47 \\
\hline May 2020 & 515,96 & 0,25 & 0,00 & 0,00 & 78,08 & 0,32 \\
\hline June 2020 & $1.366,37$ & 0,14 & 0,00 & 0,00 & 200,34 & 0,25 \\
\hline July 2020 & 646,26 & 0,23 & 0,00 & 0,00 & 132,77 & 0,28 \\
\hline August 2020. & 641,23 & 0,24 & 0,00 & 0,00 & 91,65 & 0,31 \\
\hline September 2020 & 663,35 & 0,22 & 0,00 & 0,00 & 112,04 & 0,28 \\
\hline October 2020 & 799,63 & 0,22 & 0,00 & 0,00 & 101,40 & 0,33 \\
\hline November 2020 & 737,27 & 0,21 & 0,00 & 0,00 & 93,79 & 0,29 \\
\hline December 2020 & 937,51 & 0,23 & 0,00 & 0,00 & 117,85 & 0,28 \\
\hline January 2021 & 974,89 & 0,22 & 0,05 & 0,25 & 66,51 & 0,35 \\
\hline February 2021 & 640,72 & 0,21 & 0,03 & 0,25 & 76,97 & 0,31 \\
\hline March 2021 & 947,77 & 0,22 & 0,00 & 0,00 & 123,91 & 0,30 \\
\hline
\end{tabular}

From the perspective of the grant terms, the most attractive were the loans with terms from 2 to 5 years with a share of $53.4 \%$ of the total loans granted. Legal entities hold $34.7 \%$ of these total loans. Loans in national currency were mainly represented by loans to legal entities (53.5\%). Non-financial PAGE 93| Journal of Corporate Governance, Insurance, and Risk Management | 2021, VOL. 8, Series. 1 
companies accounted for $48.6 \%$ of total loans in national currency (of which $49.0 \%$ went to trade). Loans in foreign currency were mainly requested by non-financial companies (94.7\%), the major share (58.9\%) going to trade.

The average rate on new loans granted in the national currency was $7.40 \%$, for those in foreign currency $-4.13 \%$, and for those attached to the exchange rate $-4.41 \%$. Compared to the previous month, the average rate has evolved:

- for loans in national currency rates decreased by 0.28 percentage points (p.p.). Loans were granted to legal entities with an average rate of $8.35 \%$, to individuals who practice an activity - a rate of $8.96 \%$, and to other individuals - a rate of $6.08 \%$;

- for foreign currency loan rates increased by 0.03 p.p. Legal entities were granted loans with an average rate of $4.13 \%$, other individuals - with a rate of $7.02 \%$, and individuals who practiced an activity did not resort to foreign currency loans.

- the loans attached to the exchange rate increased by 0.30 p.p. Loans were granted to legal entities with an average rate of $4.16 \%$, to individuals who practice an activity - with a rate of $5.25 \%$, and to other individuals - with a rate of $4.68 \%$.

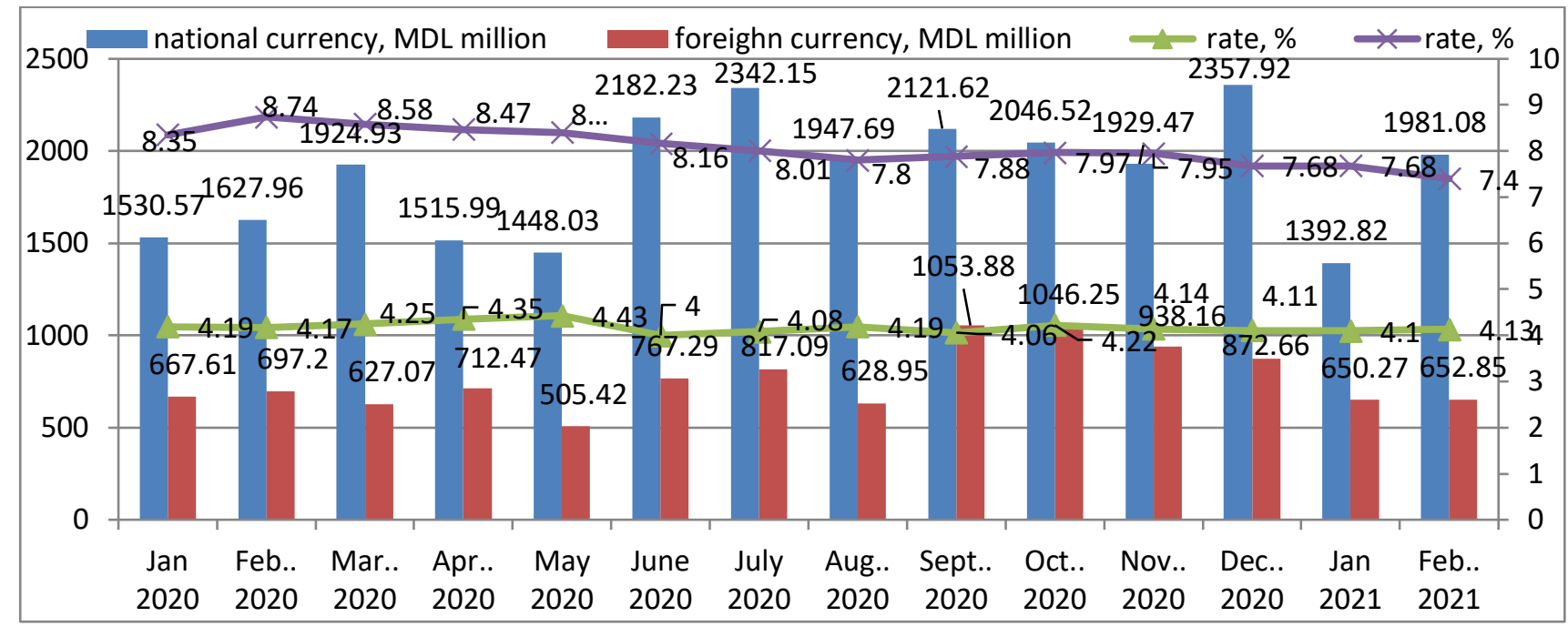

Figure 3: The weighted average interest rates and volumes on new granted loans

Compared to the similar period of the previous year, the average rate on loans granted in the national currency decreased by 1.34 p.p., on those loans in foreign currency they decreased by 0.04 p.p., and on those attached to the exchange rate it decreased by 1.20 p.p.

Banks have had to find a balance between on the one hand, reducing lending to reduce the risk of credit default, and on the other hand the need to maintain the flow of profits necessary for the operation, payment of obligations to shareholders, to the state and to one's development. The demand for bank loans from the population at this point in time will most likely create an ambiguous trend: on the one hand, the reduction in disposable income, together with the ratchet effect of consumption, will encourage the demand for consumer loans in general, and on the other hand, both due to pessimistic 
expectations about the repayment capacity and the (normal) reluctance of banks, this demand for bank loans (or acceptance of credit applications) will decrease.

During the analyzed period, there is an increase in card transactions, which indicates the willingness of users to have a cashless payment instrument, unconditional on the need to receive certain salary or social payments.

The share of active cards remained constant during the analyzed period. Social cards are the category with the highest rate of activity (75.3\%), with $61.8 \%$ of the number of operations performed with social cards being non-cash payment operations, but in value, cash withdrawals represent $80.2 \%$ of the total operations performed.

Table 4: Information regarding the activity of payment service providers with payment cards from the Republic of Moldova

\begin{tabular}{|c|c|c|c|c|}
\hline & Quarter 1, 2020 & Quarter 2, 2020 & Quarter 3, 2020 & Quarter 4, 2020 \\
\hline cards in circulation & 2.047.832 & 2.088.822 & 2.153.139 & 2.182.076 \\
\hline active cards & 1.235 .470 & 1.213 .476 & 1.264 .739 & 1.324 .843 \\
\hline salary cards & 978.188 & 975.412 & 954.825 & 961.321 \\
\hline social cards & 402.218 & 408.989 & 418.269 & 395.033 \\
\hline number of operations & 21.657.791 & 21.760 .308 & 24.930 .257 & 27.679.650 \\
\hline cash withdrawals & 6.398 .692 & 5.815 .075 & 6.645 .069 & 6.911 .528 \\
\hline non-cash payments & 15.259 .099 & 15.945 .233 & 18.285.188 & 20.768 .122 \\
\hline value of operations & 17.451.082.612 & 16.889.120.218 & 19.692.825.402 & 21.614.322.561 \\
\hline cash withdrawals & 12.580 .537 .460 & 12.058 .540 .617 & 14.154.257.534 & 15.089.306.583 \\
\hline non-cash payments & 4.870 .545 .152 & 4.830.579.601 & 5.538.567.868 & 6.525.015.978 \\
\hline self-service terminal & 22.639 & 1.134 & 1.143 & 1.120 \\
\hline ATM & 1.121 & 1.134 & 1.143 & 1.120 \\
\hline POS terminals & 21.056 & 21.504 & 22.442 & 23.727 \\
\hline installed with merchants & 18.598 & 19.044 & 19.970 & 21.234 \\
\hline including contactless & 13.973 & 15.012 & 16.136 & 18.383 \\
\hline installed with merchants & 2.458 & 2.460 & 2.472 & 2.493 \\
\hline including contactless & 422 & 420 & 431 & 438 \\
\hline e-commerce platform & 412 & 439 & 482 & 533 \\
\hline
\end{tabular}

During the third and fourth quarters of 2020, card activity indicators maintained an upward trend, with the number of cards in circulation increasing by 6.6\% (134 244 cards) compared to the first quarter and by $8.5 \%$ compared to the same period of the previous year, and the number of non-cash payments made with cards issued in the country increasing by $27.8 \%$ compared to the first quarter and by $39.8 \%$ compared to the similar period of the previous year.

With the increase of the number of cash withdrawals in the fourth quarter, the value of cash withdrawals also increases during the analysed period, but we can follow an increase of the value of non-cash payments too.

Automated remote service systems are becoming increasingly popular among users. The total number of holders of automated remote service systems compared to the same period of the previous year

PAGE 95| Journal of Corporate Governance, Insurance, and Risk Management | 2021, VOL. 8, Series. 1 
amounted to 1.9 million at the end of the fourth quarter of 2020 , increasing by $28 \%$. Of the total number of holders of automated remote service systems, $78.7 \%$ (1,640,536 holders) are registered in the automated systems of banks and $21.3 \%$ are registered in the solutions offered by non-banking service providers.

Thus, there is an increase in the number of holders of automated remote service systems at the end of the fourth quarter of 2020 compared to other quarters, which is mainly due to the considerable increase in users of mobile-payments, in the context of launching and promoting by PSP several mobile applications, as well as the constant increase in the number of registered users in internetpayment systems.

Table 5: Number of holders by types of Automated Remote Serving Systems

\begin{tabular}{|l|r|r|r|r|}
\hline & Qurter 1, 2020 & Qurter 2, 2020 & \multicolumn{1}{c|}{ Qurter 3, 2020 } & \multicolumn{1}{c|}{ Qurter 4, 2020 } \\
\hline Internet - payments & $696.225,00$ & $729.127,00$ & $791.530,00$ & $849.722,00$ \\
\hline Mobile - payments & $732.604,00$ & $778.346,00$ & $649.454,00$ & $732.328,00$ \\
\hline PC - payments & $1.217,00$ & $1.242,00$ & $1.255,00$ & $1.282,00$ \\
\hline Telephone- payments & $57.438,00$ & $57.262,00$ & $57.223,00$ & $57.204,00$ \\
\hline Grand Total & $\mathbf{1 . 4 8 7 . 4 8 4 , 0 0}$ & $\mathbf{1 . 5 6 5 . 9 7 7 , 0 0}$ & $\mathbf{1 . 4 9 9 . 4 6 2 , 0 0}$ & $\mathbf{1 . 6 4 0 . 5 3 6 , 0 0}$ \\
\hline
\end{tabular}

The number of active holders recorded an increase of $45.1 \%$ compared to the same period of the previous year, due to the need to use automated remote service systems to make payments, especially in the context of the epidemiological situation in the country, caused by the COVID-19 pandemic.

Table 6: Number of transactions performed through Automated Remote Service Systems

\begin{tabular}{|l|r|r|r|r|}
\hline & Qurter 1, 2020 & Qurter 2, 2020 & \multicolumn{1}{c|}{ Qurter 3, 2020 } & \multicolumn{1}{c|}{ Qurter 4, 2020 } \\
\hline Internet - payments & $1.469 .563,00$ & $1.797 .724,00$ & $1.638 .654,00$ & $1.704 .839,00$ \\
\hline Mobile - payments & $1.891 .578,00$ & $2.749 .831,00$ & $2.886 .079,00$ & $3.614 .846,00$ \\
\hline Total for individuals & $\mathbf{3 . 3 6 1 . 1 4 1 , 0 0}$ & $\mathbf{4 . 5 4 7 . 5 5 5 , 0 0}$ & $\mathbf{4 . 5 2 4 . 7 3 3 , 0 0}$ & $\mathbf{5 . 3 1 9 . 6 8 5 , 0 0}$ \\
\hline Internet - payments & $2.403 .386,00$ & $2.349 .443,00$ & $2.749 .153,00$ & $2.934 .816,00$ \\
\hline Mobile - payments & 878 & 365 & 740 \\
\hline PC - payments & $24.149,00$ & $24.074,00$ & $28.604,00$ & $30.527,00$ \\
\hline Total for legal entities & $\mathbf{2 . 4 2 8 . 4 1 3 , 0 0}$ & $\mathbf{2 . 3 7 3 . 8 8 2 , 0 0}$ & $\mathbf{2 . 7 7 8 . 3 7 2 , 0 0}$ & \\
\hline
\end{tabular}

In the fourth quarter of 2020, approximately 8.3 million transactions were made through the banks' automated remote service systems, $43.2 \%$ ( 2.5 million) more than in the first quarter of 2020, of which $64.2 \%$ were performed by individuals, and $35.8 \%$ by legal entities.

The value of all transactions performed through automated systems for remote service by individuals and legal entities during the fourth quarter of 2020 amounted to approximately 212.6 billion MDL , increasing by $63.3 \%$ (82.4 billion MDL ) compared to the first quarter of 2020 , with $97.7 \%$ of the value of transactions belonging to legal entities.

Table 7: The value of transactions performed through Automated Remote Service Systems, MDL

\begin{tabular}{|l|r|r|r|r|}
\hline & \multicolumn{1}{|c|}{ Qurter 1, 2020 } & \multicolumn{1}{|c|}{ Qurter 2, 2020 } & \multicolumn{1}{|c|}{ Qurter 3, 2020 } & Qurter 4, 2020 \\
\hline Internet - payments & $2.067 .710 .959,80$ & $2.041 .601 .375,90$ & $2.341 .712 .739,80$ & $2.528 .467 .401,50$ \\
\hline Mobile - payments & $1.251 .543 .122,30$ & $1.490 .771 .998,30$ & $1.685 .827 .395,90$ & $2.439 .715 .299,40$ \\
\hline Total for individuals & $\mathbf{3 . 3 1 9 . 2 5 4 . 0 8 2 , 1 0}$ & $\mathbf{3 . 5 3 2 . 3 7 3 . 3 7 4 , 2 0}$ & $\mathbf{4 . 0 2 7 . 5 4 0 . 1 3 5 , 7 0}$ & $\mathbf{4 . 9 6 8 . 1 8 2 . 7 0 0 , 9 0}$ \\
\hline Internet - payments & $125.937 .722 .464,60$ & $116.340 .309 .626,90$ & $138.770 .605 .413,90$ & $206.161 .485 .314,50$ \\
\hline Mobile - payments & $5.344 .241,70$ & $5.598 .891,60$ & $12.257 .102,30$ & $18.876 .851,10$ \\
\hline PC - payments & $934.281 .333,80$ & $802.095 .519,10$ & $1.167 .227 .907,90$ & $1.430 .280 .558,00$ \\
\hline Total for legal entities & $\mathbf{1 2 6 . 8 7 7 . 3 4 8 . 0 4 0 , 1 0}$ & $\mathbf{1 1 7 . 1 4 8 . 0 0 4 . 0 3 7 , 6 0}$ & $\mathbf{1 3 9 . 9 5 0 . 0 9 0 . 4 2 4 , 2 0}$ & $\mathbf{2 0 7 . 6 1 0 . 6 4 2 . 7 2 3 , 6 0}$ \\
\hline
\end{tabular}


During the fourth quarter of 2020, there is an increase (1.91 times) in the amount and the value (1.95 times) of transactions done through mobile-payments applications made by individuals. Legal entities mainly used internet-payments solutions to carry out transactions, registering an increase of $22.2 \%$ (approximately 531 thousand) in the number of transaction and an increase of 22.3\% (approximately 460.8 million) in the value of transactions compared to the first quarter 2020. E-commerce is becoming an increasingly popular tool for the economy.

\section{CONCLUSION}

We can conclude that the COVID-19 pandemic is ongoing and its magnitude and economic impact remain unknown. The COVID-19 pandemic and the disruption of market conditions at national and global level have a negative effect on the activity of most business segments, on the operational capacities of economic entities and, respectively, on the population. Obviously, this situation could substantially adversely affect the activity of the bank debtor, its prospects, operating results or financial situation and its ability to meet its obligations to the bank. There is no guarantee that governmental or other actions will lead to a prompt and appropriate improvement in these market conditions if the situation continues to deteriorate or if additional restrictions are imposed, or whether the current or new restrictions will be in effect for an extended period of time.

Banks were directly affected by the COVID-19 crisis, being forced to rethink their communication, sales, and marketing strategy, to revise or even renegotiate existing contracts and to analyse the directions of the evolution of their activity. Migration to digital channels has proved imperative for them, the next step is their development for the post-COVID-19 reality, which will place more and more emphasis on online and on the adaptability of banking business to consumer requirements. Changing trends in consumer behaviour could mean that building trust with customers is more important than ever.

To the extent that one can predict what the "new normal" will be for consumer behaviour, there are several assumptions. In order for banking businesses to respond effectively to post-crisis purchasing patterns caused by the coronavirus crisis, they should recognize the following trends:

- Online transactions and the use of remote service systems will become the main trend - after a period of intensified digital connectivity, customers will perceive fewer barriers to seek the assistance of technology in their daily lives.

- The need for high transparency of the operations performed and details on the conditions of delivery of products and services, aimed at increasing the degree of customer confidence in the bank.

Changing trends in consumer behaviour after Covid-19 mean that banks will have to adapt to the new requirements and needs. Of course, many things will continue to change both in the way banks act and the way they interact with their customers, but also in the provision of new products and services, 
especially in terms of digitizing customer service processes. Digitization remains a priority, in order to offer customers, the best and safest solutions in their current business and in their collaboration with business partners and, of course, with the bank.

The increasing use of digital transactions during COVID-19 is expected to continue, requiring banks to re-evaluate their channel mix to ensure robust and secure multi-channel experiences.

The future of consuming banking products and services is a combination of online and offline, based on a smartly built supply chain, to respond to a consumer whose preferences are constantly changing.

\section{REFERENCES}

Auer, R., Cornelli, G., Frost, J. (2020), “Covid-19, cash, and the future of payments”, BIS Buletin, Nr. 3, available at: https://www.bis.org/publ/bisbull03.pdf (accessed 18 February 2021).

Baicu, C., Gardan, D., Gardan, I., Epurean, G. "The impact of COVID-19 on consumer behaviour in retail banking. Evidence from Romania”, Management \& Marketing, Vol. 15, No. Special Issue, 534-556.

Baudino, P., (2020), "Public guarantees for bank lending in response to the Covid-19 pandemic”, BIS Buletin, Nr.5, available at: https://www.bis.org/fsi/fsibriefs2.pdf (accessed 18 February 2021).

BIS, (2020), "Measures to reflect the impact of Covid-19 Basel Committee on Banking Supervision”, available at: https://www.bis.org/bcbs/publ/d498.pdf (accessed 18 February 2021).

Bank of England, (2020), "Bank of England measures to respond to the economic shock from Covid19”, available at: https://www.bankofengland.co.uk/news/2020/march/boe-measures-to-respondto-the-economic-shock-from-covid-19 (accessed 18 February 2021).

Buehler, K., Conjeaud, O., Giudici, V., Samandari, H., Serino, L., Vettori, M., Webanck, L., White, O., (2020) , "Leadership in the time of coronavirus: COVID-19 response and implications for banks”, available at: https://www.mckinsey.com/industries/financial-services/ourinsights/leadership-in-the-time-of-coronavirus-covid-19-response-and-implications-for-banks (accessed 18 February 2021).

Cârstoiu, C., Ion, B. (2020), “Comportamentul consumatorului român în contextul COVID-19”, available at: file:///C:/Users/User/Downloads/comportamentul-consumatorului-roman-incontextul-covid-19-v2\%20(2) pdf (accessed 21 March 2021).

CE, (2020), "Strategia UE privind finanțele digitale", available at: https://eurlex.europa.eu/LexUriServ/LexUri Serv.do?uri=COM:2020:0591: FIN:RO:PDF (accessed 21 March 2021).

Coelho, R., Prenio, J. (2020), “Covid-19 and operational resilience: addressing financial institutions’ operational challenges in a pandemic”, BIS Buletin, Nr. 2, available at: https://www.bis.org/fsi/fsibriefs2.pdf (accessed 18 February 2021). 
Craven, M., Liu, L., Mysore, M., Wilson, M., (2020), “COVID-19: Implications for business”, available at: https://www.aedcr.com/sites/default/files/docs/mckinsey-full_article.pdf.pdf.pdf (accessed 21 March 2021).

Deloitte, I. (2021), “Global Marketing Trends: Find your focus”, available at://C:/Users/User/Downloads/2021-Deloitte-Global-Marketing-Trends.pdf. (accessed 10 April 2021).

Dinga, E. (2021), Schiță strategică "Modele economice de gestionare a șocului pandemic COVID-19”, București, Institutul Național de Cercetări Economice „Costin C. Kirițescu” - Academia Română. Economic, (2020), "Cum soluțiile digitale pot ajuta afacerile să se reinventeze pe timp de pe criză", available at: http://moldova9.com/cum-solutiile-digitale-pot-ajuta-afacerile-sa-se-reinventeze-petimp-de-pe-criza/ (accessed 18 February 2021).

eMarketer, (2020), "The biggest business impacts of the coronavirus pandemic", available at: https://www.emarketer.com/content/the-biggest-business-impacts-of-the-coronavirus-pandemicaccording-to-business-insider-intelligence (accessed 18 February 2021).

Finextra, (2020), “Coronavirus: DBS pushes 'contact free' digital banking”, available at: https://www.finextra.com/newsarticle/35366/coronavirus-dbs-pushes-contact-free-digital-banking (accessed 18 February 2021).

KPMG, (2020), "COVID-19 is changing consumer behaviour worldwide; business needs to adapt rapidly”, available at: https:/home.kpmg/ro/en/home/media/press-releases/2020/12/covid-19-ischanging-consumer -behaviour-worldwide---business-need.html (accessed 21 March 2021).

Hoe, L.K., (2020), “COVID-19: opportunities and challenges for digital banks, PWC Malaysia”, available at: https://www.pwc.com/my/en/perspective/digital/200408-pwc-blog-covid-19opportunities -challenges-digital-banks.html (accessed 18 February 2021).

McCarty, B., (2020) , “Managing customer relationships in the time of COVID-19”, BAI. Banking

Strategies, available at: https://www.bai.org/banking-strategies/article-detail/managing-customerrelationships-in-the-time-of-covid-19/(accessed 18 February 2021).

McKinsey\&Company. (2021), “COVID-19: Implications for business”, available at: https://www.mckinsey. com/business-functions/risk/our-insights/covid-19-implications-forbusiness (accessed 21 April 2021).

Melamedov, L., (2020), “Coronavirus (COVID-19) and the banking industry: impact and solutions”, available at: https://www.lightico.com/blog/coronavirus-covid-19-and-the-banking-industryimpact-and-solutions/ (accessed 18 February 2021).

National Bank of Moldova. Statistical databank, available at: https://www.bnm.md/(accessed 21 April 2021).

National Bureau of Statistics. Statistical databank, available at: https://statbank.statistica.md/(accessed 21 April 2021).

PAGE 99| Journal of Corporate Governance, Insurance, and Risk Management | 2021, VOL. 8, Series. 1 
Pop, N.A., (2020), “Contemporary Directions in the Development of Romanian Academic Marketing in Favor of Increasing the Performance of the Organization”, Springer Proceedings in Business and Economics. Springer, Cham, 17-35, available at: https://ideas.repec.org/h/spr/prbchp/978-3030-43449-6_2.html (accessed 21 April 2021).

PwC, (2020), "How retail banks can keep the lights on during the COVID-19 crisis - and recalibrate for the future", available at: https://www.pwc.com/us/en/library/covid-19/coronavirus-impactsretail-banking.html (accessed 18 February 2021).

S\&P Global Ratings, (2020), "How COVID-19 Is Affecting Bank Ratings”, available at: https://www.spglobal.com/ratings/en/research/articles/200507-how-covid-19-is-affecting-bankratings -may-2020-update-11480552

Vessey, S., Ott, C., Dimidschstein, F., (2020), "How banks can strategically respond to Covid-19 challenges”, available at: https://www.consultancy.eu/news/4096/how-banks-can-strategicallyrespond-to-covid-19-challenges(accessed 18 February 2021).

World Economic Forum, (2020), “Impact of COVID-19 on the Global Financial System Platform for Shaping the Future of Financial and Monetary Systems. Recommendations for Policy-Makers Based on Industry Practitioner Perspectives”, available at: https://www.weforum.org/reports/impact-of-covid-19-on-the-global-financial-system (accessed 18 February 2021). 